whole had been done by marine action, why does not the vertical cliff structure continue up the valley prolongation of the Fjord to the Norwegian watershed?

Benthaly Hais, near Broseley, Faithfully yours, Georgr Maw. November $10 t h, 1866$

\title{
DISCOVERY OF AMPYX NUDUS AT MALVERN.
}

In the November number of the Geologicar Magazine, at p. 519, we stated that Mr. E. B. Kemp-Welch had informed us of the discovery of Ampyx nudus in the Woolhope Limestone, at Colwall, near Malvern. We stated that the specimen of Ampyx shown to us by Dr. Grindrod, -and supposed to be that discovered by Mr. Kemp-Welch - was manufactured, and in that opinion we are confirmed by our correspondent, Dr. Harvey B. Holl, F.G.S., of Elderslie House, Worcester, who says in a letter just received, "the specimen is composed of the tail of Phacops Downingia; the rest is artificial."

Having since been favoured with a letter from Miss Fyton, of Eyton, near Wellington, dated November 3rd, stating that she was present at the discovery of Mr. Kemp-Welch's Ampyx, and can testify to its genuineness; and having also been favoured with another letter from Mr. Kemp-Welch, dated from Poole, Dorset, 5th November, protesting against the condemnation of his interesting specimen, we cannot but imagine that the Trilobite discovered by Mr. Kemp-Welch has been mislaid by Dr. Grindrod, and that the supposed Ampyx examined by Dr. Holl and myself, is one of those manufactured specimens only too frequently sold to the unwary visitor to the Malvern and Dudley districts, and accidentally placed in the Doctor's Museum. "Ampyx nudus," says Dr. Holl, "has not hitherto been found in the Malvern district."-H. W.

\section{OBITUAFY.}

Wrutua Hopkins, M.A., LL.D., F.R.S., F.G.S., so distinguished for his researches illustrative of the application of Mathematics and Physics to Geology, died in October last. We understand that for some time past his health had been gradually declining. He resigned in 1865, his fellowship of the Royal Society, to which he had been elected in 1837. In the Geological Society of London he filled the office of President, during the Sessions 1851-52, and 1852-53, previous to which, in 1850, he had received the Wollaston Medal from Sir Charles Lyell, who on that occasion, gave an outline of his principal geological researches. In 1854 he filled the office of President to the British Association at the Meeting at Hull, and held the same office in the Cambridge Philosophical Society, in which Transactions many of his most important papers were published. It is said, that he used to complain, that he could not get Geologists to understand his mathematics, nor Mathematicians to take an interest in his geology. 